Amankos MeKTEP-TEGI

Polska, Poznań

Tajżan DOSANOW

Kazachstan, Almaty

\title{
Starożytna integracja narodów Europy i Azji albo polska legenda o pochodzeniu Kazachów
}

Kości spruchniałe powstańcie z mogity. Przywdziejcie ducha i ciało i sity.

Woronicz

$\mathrm{D}^{2}$ ocent Kazachstańskiego Narodowego Uniwersytetu im. Al.-Farabi, kandydat nauk filologicznych Amankos Mektep-tegi, został skierowany do Polski w celu odbycia stażu naukowego w ramach prezydenckiego programu stypendialnego „Boloshak”. Trzeciego dnia pobytu w Poznaniu, prof. dr Marek Gawęcki, były ambasador nadzwyczajny i pełnomocny Rzeczypospolitej Polskiej w Kazachstanie, oprowadzając Panów Amankosa Mektepa-tegi i Sakena Nurbekowa po zabytkach miasta, przywiódł ich do budynku, w którym ma siedzibę Biblioteka Kórnicka Polskiej Akademii Nauk (Pałac Działyńskich). Uwagę zwiedzających zwróciła ogromna rzeźba gęsi (a właściwie coś pośredniego między gęsią a łabędziem) wieńcząca fasadę trzykondygnacyjnego budynku.

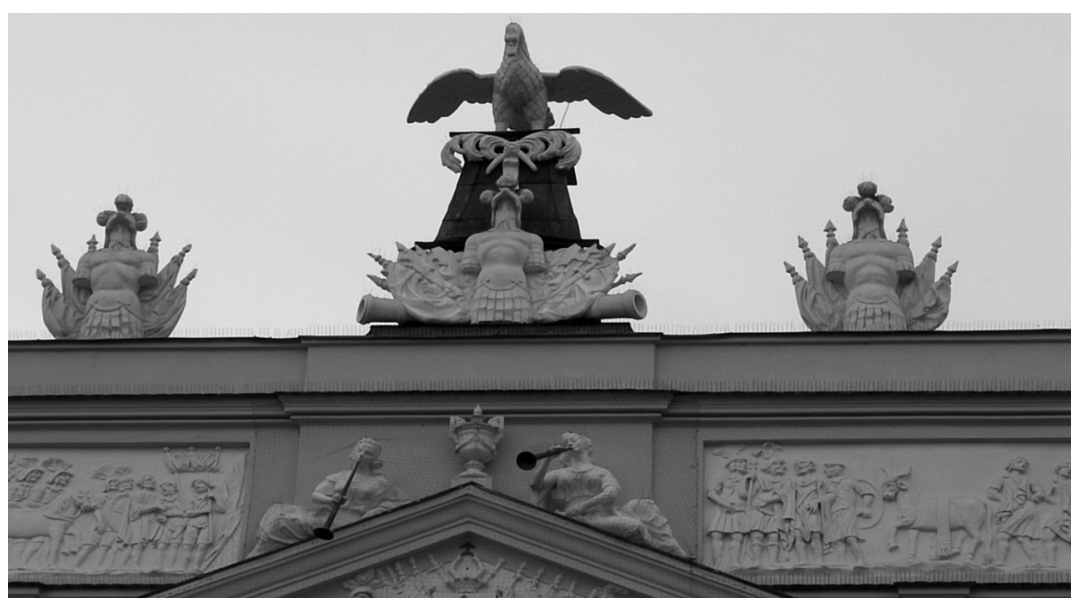


Wg świadectwa poznaniaków budowla powstała w XVIII wieku jako dzieło niemieckich budowniczych. Samo miasto, także wg słów jego mieszkańców, kilkakrotnie przechodziło z rąk polskich do niemieckich. Instynktownie odczuwając znaczenie powstania zagadkowej rzeźby, Amankos Mektep-tegi posłał do Almaty plik z fotografiami rzeźbiarskich kompozycji na frontonie budynku.

Skrupulatne zbadanie sakralnego znaczenia tajemniczych kompozycji rzeźbiarskich zaszokowało nas nadzwyczajnością informacji, którą rzeźby zawierały. Wprost nie do uwierzenia, ale milczące rzeźby opowiedziały nam nową polską legendę o pochodzeniu Kazachów!

Prawdopodobnie ta rzeźbiarska kompozycja została w swoim czasie zamówiona przez właściciela tajemniczego domu u niemieckich budowniczych. Ale z przekonaniem możemy powiedzieć, że był on Europejczykiem, dobrze znającym swoje starożytne korzenie.

Jaką informację i w jaki sposób udało nam się uzyskać? ...

Dach fasady budynku ozdabia grupa rzeźbiarska, w centrum której usytuowano metalową piramidę. Na szczycie piramidy siedzi biała gęś z rozpostartymi skrzydłami. W turkskiej mitologii Góra Świata Sumeru, zwana także Temir tau - Metalowa Góra (żelazo - kara temir) albo Altyn tau - Zlota Góra, niekiedy przedstawiana jest jako piramida. U podstawy piramidy znajduje się statua wodza, z jego prawej i lewej strony umieszczono jeszcze dwie kopie statuy. Nie mają one rąk i nóg i dowodzą w ten sposób, iż mamy przed sobą założyciela rodu көк Turków (Niebiańskich Turków) Aszinę!

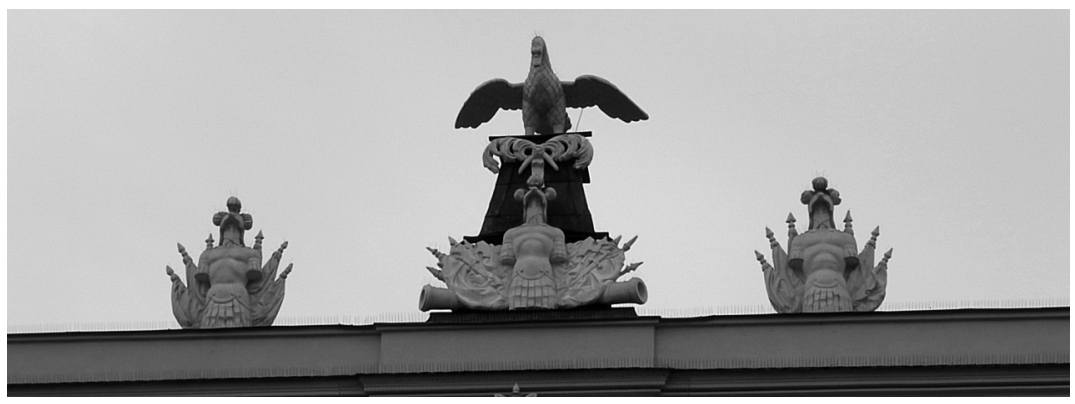

Trzy statuy wodza świadczą o swego rodzaju troistości, co potwierdzają także potrójne ozdoby z piór na hełmach każdej statuy. Za ich plecami, na kształt swego rodzaju skrzydeł, umieszczono choragwie, po trzy na prawej i trzy na lewej stronie, co przypomina dwa skrzydła, dzielące się z ko- 
lei na trzy buzuki i trzy uciuki, co określono w naszym badaniu jako Alty Alasz-sześć kosmicznych obiektów (T. Dosanow, Tajemnica run, 2009, s. 94-98, 171-174).

Usta statui są szczelnie zakryte zawiązanymi na krzyż opaskami, co świadczy o najsurowszym tabu na informację przekazywaną przez rzeźbiarską kompozycję i, odpowiednio, o zakazie przekazywania jej niegodnym tego osobom.

Poniżej, wewnątrz frontonu (trójkątna część fasady budyn$\mathrm{ku}$ ), na podtrzymywanej przez dwa lwy płycie, zamieszczono znak, przedstawiający tamgę , stworzoną $\mathrm{z}$ dwóch prostych: $\uparrow \mathrm{i} \cap$.

Znaczeniu symboli przypatrzy-
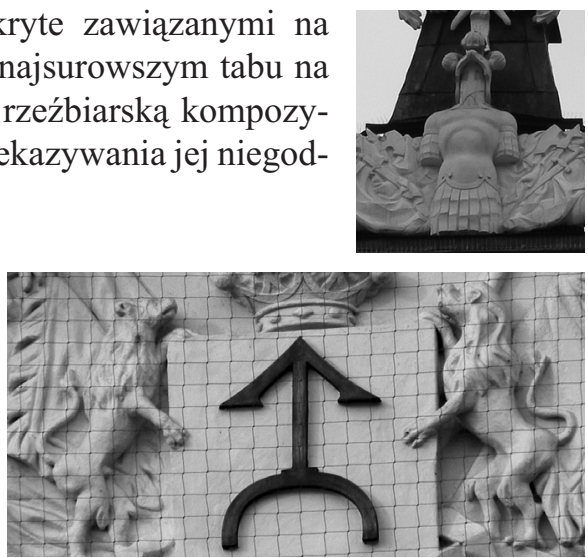
my się dokładnie poniżej. Zwracamy uwagę, że właśnie ta tamga pozwala nam mówić o związku Turków z tajemnicą poznańskiej kompozycji rzeźbiarskiej.

Główną figurą wyżej przedstawionego kompleksu jest niebiański ptak Kazak (Kaz-gęś+Ak-szlachetna), czyli Szlachetna Gęś albo Labędź. (Tajemnica run, s. 79).
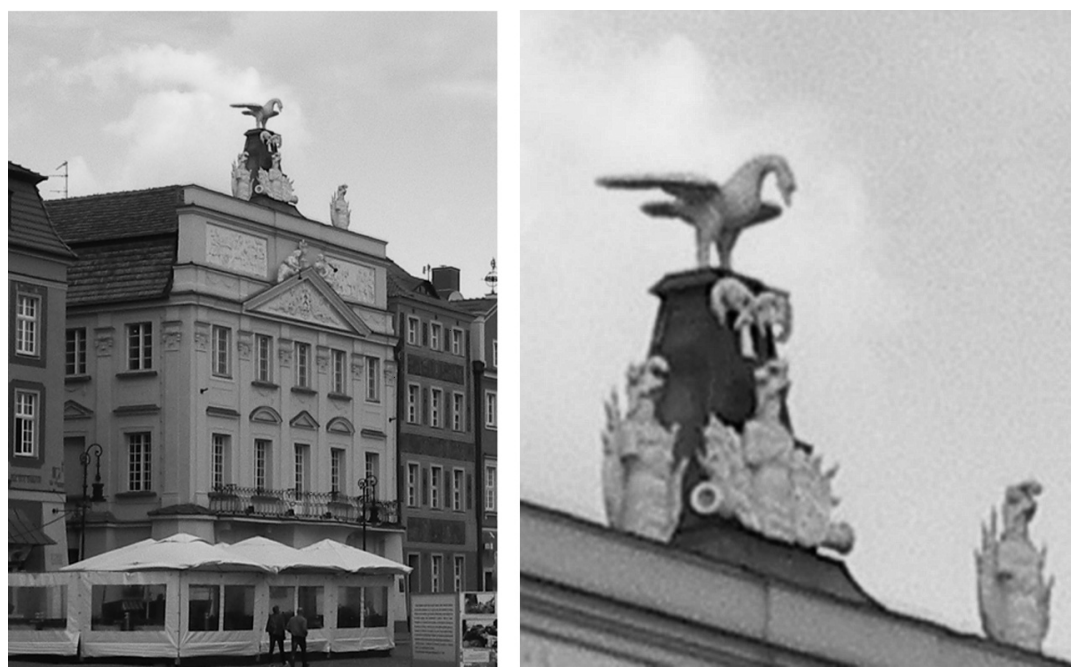
Niebiański ptak Kazak jest pełnoprawnym gospodarzem Bengi Көк Tengri - Wiecznego Niebieskiego Nieba, to jest tej części niebieskiej sfery, w której znajduje się Ocean Słodkiej Wody. Trochę poniżej wierz-

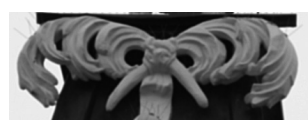
chołka ostrosłupa ściętego, przedstawiającego Górę Świata, usytuowano dwie skrzyżowane gałęzie, symbolizujące Drzewo Świata.

Wg legendy, spisanej przez I. I. Krafta, znużone wojsko zastawiło w bezwodnym stepie swego chorego wodza: „... Wszyscy współczuli Kalczy, ale dopomóc $\mathrm{w}$ nieszczęściu nie mogli i niczego nie wymyślili. W końcu, licząc na Bożą łaskę, postanowili zostawić wodza w stepie. Wojsko ruszyło w drogę. Dzień wydawał się niesamowicie gorący, z każdą minutą rosły cierpienia Kalczy nie było zaś nikogo, kto by dopomógł choremu i go pocieszył. Zbliżała się śmierć ... Zebrawszy ostatnie siły, ze świadomością nieuniknionej śmierci, Kalcza podniósł się na kolana i zaczął modlić się o rychłą śmierć, wybawicielkę od potwornych mąk ...

Nagle wydarzył się cud. Wysłuchawszy skarg nieszczęsnego weterana niebiosa rozstąpiły się i przyleciała do niego kaz-ak, biała gęś. Ptak pocieszył Kalczę-Kadyra, poleciała po wodę i szybko wzmocniła jego siły na tyle, ze przestał on myśleć o swoich cierpieniach i nieszczęściu. W postać gęsi wcieliła się jedna $\mathrm{z}$ dobrych peri. Ta dobra i miłosierna peri przemieniła się z gęsi w cudowne stworzenie i została z Kalczą. Z małżeństwa Kalczy i dobrej Peri urodzili się ludzie, potomków których, na pamiątkę niezwykłego zjawienia się przed Kalczą wybawicielki i rodzicielki, zaczęto nazywać kaz-ak, albo kajsak" (I. I. Kraft, Zbiór aprobat o Kirgizach z obszarów stepowych, 1893, s. 3). W rzeczywistości imię przodka Kazachów Kalcza-Kadyr, gdzie kalcza oznacza „ten, który pozostal”, a kadyr w języku południowoturkskim znaczy: 1) odrzucać, odtrącać; 2) surowy, okrutny (Stownik starożytnego języka turkskiego, L. 1969, s. 403). W całości imię Kalcza-Kadyr znaczy Pozostając Odwróconym (od) Okrutnej (śmierci) i odpowiada sytuacji przedstawionej w legendzie.

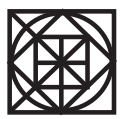

W drodze nałożenia na siebie 43 znaków starożytnych turkskich run, zrekonstruowaliśmy tablicę bazową - Piczin, przedstawiającą synchroniczny skrawek graficznego aspektu run; te same znaki, ustawione diachronicznie (postępująco) w ustalonym przez nas porządku i odczytane jak hieroglify, tworzą jakiś tekst sakralny, nakazujący znalezienie Wladcy Wody i Władcy Ognia (Tajemnica run, s. 32-34). Wpisane w tablicę koło symbolizuje Niebiosa. Przy poszukiwaniach Władcy Wody krąg rozdziela się na pół, imitując rozwarte niebiosa 
w legendzie o prarodzicu narodu kazak. W powstającej „szczelinie” w cudowny sposób pojawia się znak niebiańskiego ptaka:

KazaK (palindrom)

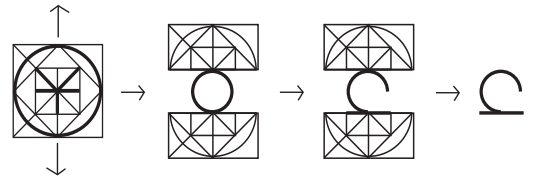

Kim jest on, ten niebiański ptak, i w której części nieba się znajduje? Tamga Kuszan-Ptasie Koło przedstawia Niebiańskiego Ptaka Kazak. Analiza znaków graficznych tamg $\boldsymbol{\delta}$ - Kuszan (Ptasie Koło) i $S$ - Ŝylbyr (Beczewa, to znaczy Przywiązana) doprowadziła do wniosku, że razem znaczą one $\delta+{ }=\delta$ - Środek Lata.

Połączone razem tamgi odzwierciedlają położenie Małego Wozu (gwiazdozbiór Małej Niedźwiedzicy) w porze wieczornej w połowie miesiąca lipca. Słuszność naszej interpretacji potwierdza tamga $\delta$ - Kerteri (kert-znak + eri-miejsce $=$ Oznaczone Miejsce), ustalająca położenie Małego Wozu na niebie w środku lata. A zatem niebiański ptak KazaK jest jakąś personifikacją Wozu, połączonego z Gwiazdą Polarną i krążącego wokół niej. Należy pamiętać o tym, iż wszystkie gwiazdy na niebie krążą wokół Niebieskiej Osi, przechodzącej niedaleko od Krzyża Południa poprzez oś ziemską do Gwiazdy Polarnej. Nieruchoma jest tylko Gwiazda Polarna!

Niebiański ptak Kazak, przedstawiony w postaci Małego Wozu, rozdziela Słodką Wodę wg pór roku:
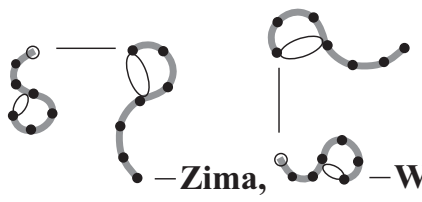

Wiosna,
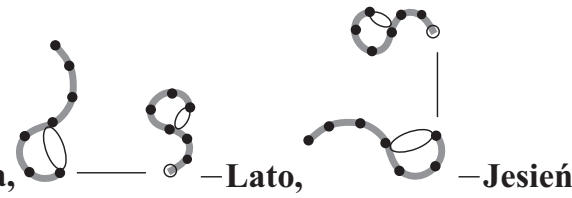

W połowie pory roku, gdy tylko na niebie zapalą się wszystkie gwiazdy, Mały Wóz zajmuje na niebieskim nieboskłonie jedną z przedstawionych wyżej pozycji. Na uwagę zasługuje fakt, że tamga Kuszan-Ptasie Koło przedstawia Niebiańskiego Ptaka Matkę KazaK wysiadującą Dwupłciowe (męskie i żeńskie) Niebiańskie Jajko:

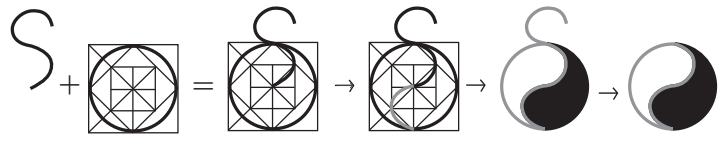


- symbolizujące Ziemię w środku lata! Niebiańskie Jajko to kosmiczny symbol In-Jan, odzwierciedlający Ziemię z zamieszkującymi ją żywymi istotami, a Niebiański Ptak Matka KazaK to matka wszystkich żywych istot! Idąc dalej, Niebiański Ptak KazaK to turkska bogini płodności Umay-Ana!

Niebiański Ptak KazaK jest prawdziwą Władczynią (Oceanu Słodkiej) Wody. Jest ptakiem, którego starożytni Słowianie przedstawiali wewnątrz ośmiopromiennej gwiazdy z elipsą pośrodku i nazywali:

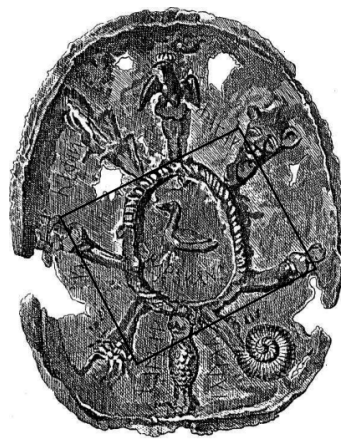

Ptak Matka Swa (Aleksander Asow, Runy Stowian $i$,Bajanowy hymn")

Przedstawiali go także w postaci Łabędzia w elipsoidalnej klatce z ukośną kratką!
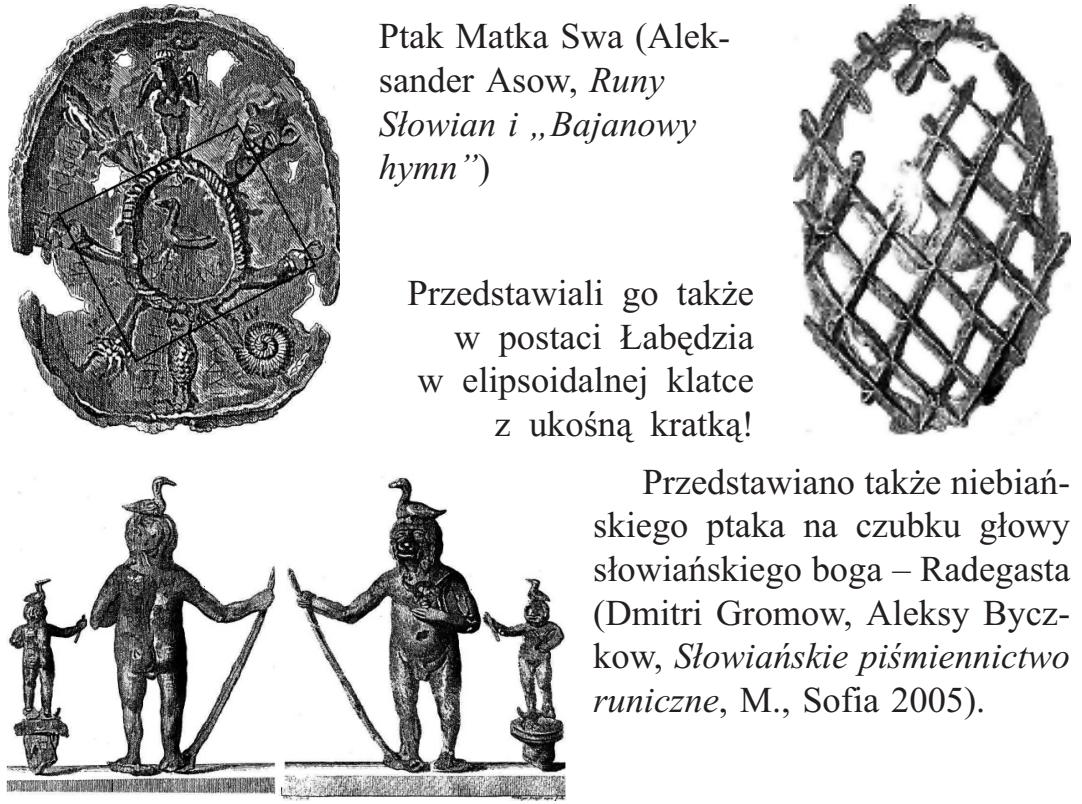

Przedstawiano także niebiańskiego ptaka na czubku głowy słowiańskiego boga - Radegasta (Dmitri Gromow, Aleksy Byczkow, Stowiańskie piśmiennictwo runiczne, M., Sofia 2005).

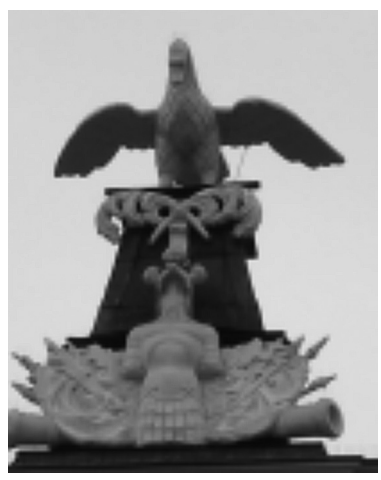

Umieszczenie statuy założyciela rodu KeK Turków pod niebiańskim ptakiem Kazak wskazuje na to, że Aszyna znajduje się pod jego protekcją i obroną.

W chińskich źródłach zachowała się legenda o dziesięcioletnim chłopcu z rodu Aszyny, który zapoczątkował ród $\mathbf{K} \ominus \mathbf{K}$ Turków albo niebiańskich Turków: „Przodkowie tukueskiego Domu zamieszkiwali na zachód od zachodniego morza i sami tworzyli ajmak. Jest to oddzielna gałąź Domu Hann noszącego 
przydomek Aszyna. Po pewnym czasie cały ród został podbity przez sąsiedniego władcę i całkowicie wyniszczony. Przy życiu uchował się tylko dziesięcioletni chłopiec. Wojownicy, widząc jego małoletniość, ulitowali się nad nim i odrąbawszy mu ręce i nogi, wrzucili go w trawiaste jezioro. Wilczyca zaczęła karmić go mięsem. Władca usłyszawszy, że chłopiec jeszcze żyje, powtórnie posłał swoich ludzi, aby go zabili. Ci, zobaczywszy chłopca obok wilczycy, chcieli zabić także ją. W tym czasie, wg chińskich opowieści, wilczyca ta pojawiła się w kraju na wschód od zachodniego morza, w górach leżących na północny-zachód od Gao-czan. W górach znajduje się kotlina, a w kotlinie równina porośnięta gęstą trawą w promieniu kilkuset li. Ze wszystkich czterech stron pieczara otoczona jest górami. Tu ukryła się wilczyca i urodziła dziesięciu synów, którzy podrósłszy, ożenili się i wszyscy mieli dzieci. Po pewnym czasie każdy z nich stworzył oddzielny ród. Wśród nich był Aszyna, człowiek bardzo utalentowany, i jego uznano za władcę; nad bramą miejsca swego pobytu, na pamiątkę swego pochodzenia, umieścił wilczą głowę" (Biczurin, Zebranie wiadomości o narodach zamieszkujacych Środkowa Azję w starożytnych czasach).

Ale na budynku Polskiej Akademii Nauk obok młodzieńca z odrąbanymi rękoma i nogami nie widzimy wilczycy, lecz niebiańskiego ptaka KazaK. Zatem, w legendzie o pochodzeniu chory wódz Kadyr Kalcza, straciwszy w walce ręce i nogi, pochodził z rodu Aszyny. Opaska, zawiązana na ustach statuy wodza świadczy o tym, iż ta informacja okryta jest tajemnicą. Zgodnie z tym, prości ludzie i chińczycy byli wtajemniczeni w zmienioną wersję legendy, w której wodza z rodu Aszyny przedstawiono jako dziesięcioletniego chlopca, i którego od śmierci uratowal nie ptak KazaK, lecz Wilczyca!

Władcy narodu KөK turuk-niebiańscy Turkowie, są przedstawicielami rodu gyade albo ade(a-de, adie, ahi, ediz). Tamga rodowa $\boldsymbol{X}$-a-de (U. A. Zujew, Tamgi koni z wasalnych księstw, Prace IIAE Kaz. SSR, t. 8, 1960, s. 132), w rzeczywistości składa się z dwóch tamg starożytnego rodu kazachskiego adaj $\boldsymbol{U}+\boldsymbol{\Lambda}=\boldsymbol{X}_{\text {(T. Dosanow, Tajemnica run, Al- }}$ maty 2009, s. 68). Dolna tamga: $\mathbb{\wedge}$ przedstawia Górę Świata z wyobrażeniem rzeki mającej swój początek na jej wierzchołku. Adajowie swoją podstawową tamgę, której różnorakie warianty graficzne umieszczano na tamgowych i nagrobnych kamieniach, nazywają: Sadak-Ok - Łuk-Strzała, co konkretnie przedstawia górna tamga: $\boldsymbol{U}$. Ta tamga znana jest pod nazwą Jaj tamga-Łuk tamga. Jaj tamga, umieszczona na tamdze Góra 
Świata, przedstawia odpowiednio $\boldsymbol{\Lambda}$ - Błyskawicę (w języku kazachskim) - podstawową broń Władcy Wody (Deszczu), którego symbolizuje Niebiański Ptak.

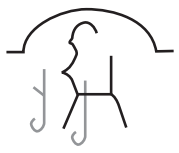

Przypatrzmy się rodzinnej tamdze - gjad'e (adaj) umieszczonej na ogninskim zabytku (S. E. Malov, Zabytki starożytnego piśmiennictwa Mongolii i Kirgizii, M.-L. 1959). Łuk w jego górnej części, zwanej w starożytnym języku turkskim $\bigcap$ - ujug+or=wygięte +podniesione, ilustruje nieboskłon, na którym znajduje się ocean słodkiej wody $\mathbf{O g}+\mathbf{U z}$, co znaczy Ukryta+Rzeka. Znaczenie tej tamgi znalazło się u podstawy powstania w gaogjujskiej konfederacji nowej nazwy Ujgur, znanej w językach chińskich jako Hojhor albo Ojhor. Z zaprezentowanego wyżej materiału wynika, że terminy Oguz i Ujgur to synonimy określające przestrzeń, w której zamieszkują jeszcze nienarodzone dzieci Niebiańskiej Matki KazaK.

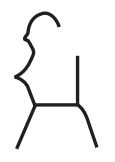

Chańska tamga tjukjuesskiego rodu - gjad'e (adaj) - przedstawia wizerunek górskiego kozła $\mathbf{z}$ nierealnie długim ogonem ... W rzeczywistości ten detal jawi się jako podpowiedź dla odgadnięcia prawdziwego znaczenia danej tamgi. Po rozsunięciu tamgi złożonej z dwóch elementów:

$$
\xi=S+\{1
$$

widzimy, iż składa się ona z adajewskiej tamgi $S$ - Ŝlbyr (Przywiązana) i stylizowanego wyobrażenia psa gończego $)$ - Adaj (adaj-gończy pies we współczesnym hakasskim języku). W starym, mówionym języku hakasskim słowo adaj znaczylo wilk. W starożytnym języku turkskim słowo adaj oznacza: 1) Pisklę; 2) Dziecię (Słownik starożytnego języka turkskiego, L. 1969, s. 8). Przedstawione rudymentarne znaczenia rodowego terminu świadczą o tym, że jeden z totemicznych rodziców Adaâ to bez wątpienia ptak, a zgodnie z tamgą Šylbyr nietrudno określić, że to niebiański ptak KazaK, przywiązany do Gwiazdy Polarnej. Na podstawie zachowanej części gâd'esskiej tamgi przedstawiającej gończego psa, nietrudno także określić, iż drugim z totemicznych rodziców Adaâ był Wilk. Później, takaż chańska tamga, ale już z kilkoma zmianami (psu gończemu dodano nieco dłuższą lapę):

$$
\left\{={ }^{5}+\gamma\right.
$$

została przedstawiona na pomniku Kul'-Tiginu. 
Zaznaczmy, że ród Adaj (Ad'e) był częścią oguzskiego związku rodów tokuz oguz, posiadającym jednoimienną tamgę $/($ - tokuz oguz. W koncepcji runicznej koło, zgodnie z liczbą miesięcy rocznego cyklu krążenia Ziemi wokół Słońca, posiada liczbowy odpowiednik dwanaście; połowa koła - sześć; jedna czwarta koła - trzy. Obwód szyi w wizerunku ptaka $\subseteq$ - KazaK stanowi niepełny okrąg, odpowiadający dziewięciu miesiącom. To oznacza, że Niebiański Ptak Matka KazaK nosił Adaâ (Dziecię, Pisklę) w swoim łonie przez okres dziewięciu miesięcy! Znaczy to, że Niebiański Ptak KazaK to Matka, a imię jej - Kobieta!

$\mathrm{Na}$ frontonie poznańskiego pałacu przedstawiona została tamga $⿱$ 今, która - co uprzednio zauważyliśmy - składa się z dwóch adaevskich tamg 个 - Strzala + Luk - .

Na uwagę zasługuje fakt, iż na tamdze przedstawiono jakby początkowy moment oddzielania się strzały od łuku. Połączone tamgi posiadają także drugie znaczenie: $\boldsymbol{\uparrow}$ - Og (ukryty) + Uz (rzeka, ocean) $-\frown$, co w całości oznacza $⿱$ 今 - Oguz + Ukryta Rzeka, albo Ocean Słodkiej Wody! Poza tym tamgi posiadają inne tajne znaczenia, lecz nie musimy się tym zajmować w ramach niniejszego artykułu.

Prawdziwą władczynią Tajemniczego Oceanu (w którym ukrywają się dusze ludzi, nie tylko te, które po raz pierwszy posyłane są do ziemskiego lub materialnego świata, ale także przygotowujące się do reinkarnacji) jest tylko ona - Niebiańska Matka KazaK! Oto tamga

- Ujgur, inaczej zwana Oguz = Ukryta Rzeka, zooteryczna przestrzeń, w której ukrywały się wszystkie dzieci-pisklęta Niebiańskiej Matki KazaK! Dziś tylko niewielka ich część nazywana jest Kazachami! Podstawowa zaś część już nie pamięta, iż kiedyś potrafiła latać.

Na podstawie przedstawionych wyżej materiałów, pochodzenie starożytnych terminów turskich $\mathrm{K} \Theta K$ turuk (przywiązani do nieba), albo KөK toruk (niebiańscy wybrańcy) należy łączyć z Niebiańskim Ptakiem KazaK.

Nad płytą z tamgą przedstawiono królewską koronę, z wnętrza której na brzegach wyłaniaja się miecz i berło, bez wątpienia symbole władzy królewskiej. Z centralnej części korony wychodzą wyobrażenia rąk (ręce Matki KazaK), mocno trzymające tamgę Strzała i Łuk. Tamga wbija się w górny występ frontonu, imitujący tamgę

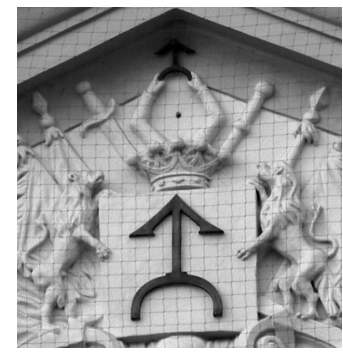




\section{人 - Alšin (Al+Šin=Weź+Prawdę), albo Ašin(a)=(Ǎs $+\check{S} i n=O d k r y j+$} +Prawdę). Ta tamga uważana jest za wspólną dla wszystkich Alšinców! Umieszczając ogólnoplemienną tamgę alšin razem z tamgą dowolnego alšinskiego rodu można otrzymać o tej ostatniej dodatkową informację.

Zgodnie z informacjami, przekazanymi przez Teofana Ispovednika: „Chazarowie - wielki naród, który wyszedł z Bersilii” (S. A. Plemneva, Chazarowie, Moskva 1976, s. 15). Nazwę kazachskiego rodu Berš w źródłach arabskich pisano w różny sposób: brš, albo brs. Kraj nazywany w źródłach arabskich jako Bersilia, albo al(') Baršalia, znajdował się na terytorium współczesnego Dagestanu. Bers+il' niekiedy nazywany jest Basilem (bas - główny+il' - ród). Wynika z tego, że w Chazarii rządził ród Ašina, władający na Kaukazie od czasów Bymyn-kagana. O władzę w kaganacie walczył także ród Dulu (tulu), wchodzący w skład gaogjujców, od których w istocie pochodzi związek rodów tokuz oguz, w chińskich kronikach nazywany hojhor (ujgur). Pletneva przekazuje taką informację: „Kubrat należał do rodu Dulo (Dulu), który w Turkskim kaganacie walczył o władzę ze sprawującym rządy rodem Ašina" (S. A. Plemneva, Chazarowie, Moskva 1976, s. 21).

Poznańska kompozycja rzeźbiarska pozwala wyciąnnąć wniosek, iż ptak KazaK miał trzech synów. Kazachowie od niepamiętnych czasów dzielili się na trzy žuzy. W starożytności Alšincowie żyli w Siedmiorzeczu, i w chińskich kronikach nazywano ich da-juečži, to znaczy duzi-juečži. Jednakże w tekście ilijskiego pomnika rody, zasiedlające te ziemie, zwą siebie Az albo Az Eli - Azskij lud (T. Dosanow, Tajemnica run, 2009, s. 280-287). Należy jednak zauważyć, że Chińczycy często zniekształcali imiona swoich sąsiadów. W III w p.n.e. Siedmiorzecze zaczynają zasiedlać Usunowie i po pewnym czasie już oni nazywają się Wielkim Žuzem.

Bardzo interesujące byłoby poznanie, do której fali wędrówki ludów należeli przodkowie Europejczyków, którzy pozostawili na fasadzie poznańskiego pałacu tajemnicze informacje o swoim pochodzeniu. Jeśli nie brać pod uwagę częstych wędrówek azjatyckich Scytów jeszcze przed naszą erą, to pierwsza wielka fala migracji Azjatów do Europy nastąpiła wraz z wyprawami Atylli w latach 441-453. W ich wyniku duża część wojowników pozostawała na podbitych ziemiach i nieuchronnie poddawała się procesowi asymilacji. Należy podkreślić, iż koczownicy wędrowali do Europy z rodzinami (na wozach). Znany jest w historii przypadek, kiedy syn bułgarskiego chana Kobrata - chan Asparuch (z rodu dulat), z całą swoją ordą przeniósł się z nadczarnomorskich stepów nad Dunaj. 
Tam, połączywszy się ze spokrewnionymi Dulebami-Słowianami (dulatami z czasów Atylli), stworzyli Bułgarię. Druga duża fala wędrówki ludów nastappiła wraz z wyprawami Bumyn-kagana w 552 roku. W zabytku Kul-Tiginu wzmiankują o wyprawach Bumyn-kagana i Istemi-kagana następujące wersy: ,... z przodu od Kadyrchanskiego płaskowyżu, z tyłu do Żelaznych Wrót zasiedliliśmy ich". Żelazne Wrota to określenie chazarskiego miasta Derbent (Debir - Żelazny + kent - miasto (O. Sulejmenov, Az i $\hat{A}$, 1975).

Rozpadowi kachanatu chazarskiego, spowodowanemu uciskiem stepowych Chazarów (Czarnych Chazarów), towarzyszył nieprzerwany odpływ ludów na zachód - do Turcji, Serbii (na Morawy), na Węgry, do Polski, Niemiec i na Litwę. Według wszelkiego prawdopodobieństwa wytrawnych i nieustraszonych wojowników chazarskich, którzy zwracali się $\mathrm{z}$ prośbą o przyjęcie w poddaństwo, wszędzie witano bardzo serdecznie. Uważa się, iż husarze pojawili się na Węgrzech w drugiej połowie XV wieku, kiedy król Maciej Korwin, zwycięzca Turków, wyznaczył państwową powinność. Nazywała się ona „huszar”, co Węgrzy etymologizują w sposób następujący: husz - dwadzieścia i ar - pieniądze. Pieniądze te przeznaczano na każdego 20-go spośród spisu poddanych, którzy powinni pełnić służbę wojskową. Uważamy jednak, że ta stosunkowo późna etymologia nie wydaje się być właściwa. U starożytnych Turków wojownicy z przymocowanymi (w późniejszych czasach przypiętymi) skrzydłami nazywali się hussar, a słowo to pochodzi od starożytnego turkskiego huss - ptak + er - wojownik i, podlegając zasadom turkskiej syn harmonii, mogło brzmieć kusar lub gusar. Zapewne nieprzypadkowo na północy Azerbajdżanu znajduje się miasto Qusar. Z miasta Qusar do miasta Derbent (̇̇elazne Wrota) jest $49 \mathrm{~km}$. Przypomniawszy sobie wers na zabytku Kul-Tiginu: ,... z przodu od Kadyrchanskiego płaskowyżu, z tyłu do Żelaznych Wrót zasiedliliśmy ich", zwróćmy uwagę, że jest to terytorium kachanatu turkskiego.

Nie należy wykluczać etymologii terminu кұcap ot Kұc-ap oznaczającego szlachetnego ptaka, KazaK, zestawionego analogicznie z terminem hazar. Zauważmy, że termin hazar pochodzi od kazar=kaz+ar, w znaczeniu szlachetna gęś, zwracając uwagę na fakt, że dźwięk (h) pojawił się u Turków po przyjęciu islamu.

Oznacza to, że terminy KazaK i Kazar to synonimy. Godnym uwagi jest też fakt, że na zachodzie Azerbajdżanu istnieje miasto Kazah (Qazah). Nie zaszkodzi w tym miejscu dodać, że według Konstantina Bagrânorodnogo, na Kaukazie był kraj Kazahiâ: „Powyżej Zuhii leży kraj, 
zwany Papagiâ, powyżej Papagii - kraj o nazwie Kasahiâ, powyżej Kasahii znajdują się Kaukaskie Góry" (Konstantin Bagrânorodnyj, O rzq̨dzeniu imperium).

W planie fonetycznym wypowiedziane przez Kazacha słowo кұсар zostanie usłyszane przez nie-Kazacha jako gusar. Istnieje jeszcze jedna ważna okoliczność, związana z tym, iż słowo кұ̣c - ptak w turkskich językach tylko przez Kazachów wypowiadane jest przy pomocy (s) na końcu słowa, podczas gdy pozostali Turkowie wypowiadają to słowo jako кұш, гуш [guš], z użyciem głoski š na końcu słowa. Bardzo ważny jest i ten fakt, że europejscy husarze obowiązkowo golili brody, choć ich przodkowie nie golili ich zupełnie, ponieważ byli kose - bezbrodymi, a rosły im tylko wąsy!
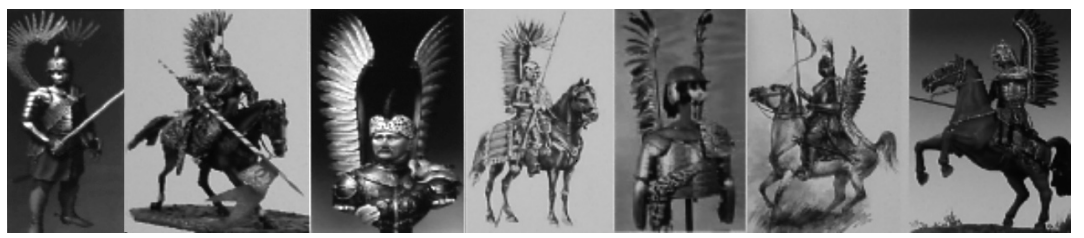

Po pewnym czasie, potomkowie kusarów, rodzący się z mieszanych małżeństw, już golili brody. W polskim wojsku husarze uważani byli za elitę, odznaczającą się szaleńczą odwagą. Skrzydlaci jeźdźcy byli także w osmańskiej armii, gdzie nazywano ich deli - szaleńcy, ale stanowczo nie kusar. Turecki parzysty formant przeczenia - deil - nie może być używany także oddzielnie: albo w żartobliwej formie Deli, oznaczającej szaleńcy, postrzeleńcy, albo $\mathrm{w}$ pogardliwej formie deli - bezmyślny. Podstawowa część prawdziwych skrzydlatych husarzy z dawien dawna osiedliła się w Polsce, o czym bez wątpienia świadczy rzeźbiarska kompozycja poznańskiego pałacu. Co więcej, najlepszych spośród husarzy obdarzono tytułami dworzan i oni nie żałowali ni sił, ni życia dla interesów i pomyślności państwa polskiego.

Król Polski Stefan Batory (1576-1586) w związku z uzbrojeniem husarzy wydawał następujące zarządzenia: „... a ci żołnierze, którzy będą służyli w husarii, powinni mieć dobre konie; udając się na wojnę winni siadać na konia z kopią, w zbroi, w nałokietkach, w hełmie, z krótką bronią, z szablą, z koncerzem lub z pałaszem ...”. Jest to typowy portret wojownika-koczownika. Wiadomym jest, iż długi polski miecz koncerz został zapożyczony przez Słowian od Turków. Także polski żupan albo pikowany kaftan mają wspólne korzenie ze starą kazachską odzieżą syry- 
lgan šapan (pikowany kaftan z podszewką z wielbłądziej albo owczej wełny).

W ten sposób skrzydlaci husarze, w skład których wchodziły kazachskie rody, walczyli w wojskach Stefana Batorego, Jana Sapiehy i hetmana Chodkiewicza. Stefan Batory w latach 1579-1582 dowodził polskimi wojskami w wojnie o Inflanty i osiagnął szereg zwycięstw nad wojskami rosyjskimi. Po wtargnięciu na terytorium rosyjskie, bez sukcesu okrążał Psków (sierpień 1581-luty 1582) i w końcu zawarł z Iwanem IV pokój, na mocy którego Rosja zrzekła się swych roszczeń do Liwonii. Iwan Groźny w posłaniu do Stefana Batorego niejednokrotnie napomykał o tym, iż był on wasalem sultana tureckiego (np. ,że prosisz o powstanie, to wtrącono $\mathrm{z}$ bisurmańskiego obyczaju: takie żądania stawiają Tatarzy, a w chrześcijańskich krajach tak się nie postępuje...”). Wywołało to ostrą odpowiedź Batorego ,jak nam śmiesz tak często przypominać bisurmaństwo, ty, który krew swoją z nami pomieszałeś, którego przodkowie kobyle mleko, co kapnęło na grzywy tatarskich kobył lizali ...” (Henryk Štaden, Zapiski Niemca-oprycznika, redakcja i komentarze kandydat nauk historycznych S. Û. Šokareva, M. 2002). Należy zauważyć, iż w Europie, i także w ZSRR, w odniesieniu do turkskich narodów przez długi czas używano terminu Tatar, będącego synonimem dzisiejszego terminu Turk, którego zaczęto używać dopiero w roku 1920 w Baku. Ale na tytułowej stronie podręczników szkolnych (z lat 1950-1960) do języka kazachskiego, albo języka azerbejdżańskiego, jeśli się nie mylę, była uwaga: (dla tatarskiej szkoły). Godne uwagi, że w runicznej etnoplemiennej koncepcji termin Tatar znaczy tyle, co Orzel (Tajemnica run, s. 110).

Nazwisko króla polskiego Stefana Batorego pochodzi ot turkskiego Bator - Bohater. Dawność tego leksemu potwierdza tekst runiczny drugiego zabytku jenisejskiego, gdzie był on przedstawiony w formie batur lub Bator - bohater (S. E. Malov, Jenisejskie piśmiennictwo Turków, M-L 1952 , s. 8). W turkskiej runice litery „o" $i$ „u” były oddawane za pomoca jednego znaku $<=\mathbf{0}$,u.

Nieprawdopodobne, ale polskie imię Kazimierz jest także turkskie. Powstało ono z Kaz-Gęś + Imir = Emir-Wladca. Pramatka wszystkiego, co żywe, totemiczny ptak Kaz rzeczywiście jawi się jako władczyni wszystkiego, co żyje na Ziemi. Posiadacz imienia bez wątpienia znajdował się pod niezawodną ochrona, ponieważ było ono w istocie zwróceniem się do niebiańskiego ptaka i implicite zawierało prośbę: (Strzeż) Kazimierz-Gęś+Władca! Imię Kazimierz podobało się Polakom, gdyż w tym imieniu słyszeli oni słowiańskie Kazi-Mir, oznaczające Poka- 
zujący+Mir (Pokój), Objawiający+Mir (Pokój), Niosący+Mir (Pokój). Chociaż, jako reguła, imiona przedstawicieli tatarskich (turkskich) rodów: Alšin, Žalair, Najman, Ujšun, a także Tatar mišcislavcev i Tatar kleccev nieustannie zmieniały się na polskie (Stanisław Dziadulewicz, Herbarz rodzin tatarskich w Polsce, Wilno 1929. W tym miejscu wyrażamy głęboką wdzięczność Panu Profesorowi Henrykowi Jankowskiemu za udostępnienie książki Stanisława Dziadulewicza).

W Polsce nikt nie powiedział nam niczego konkretnego o rzeźbiarskiej kompozycji na pałacu w Poznaniu. W roku 1855 ukazała się we Lwowie książka Niesieckiego Heraldyka Polski pod redakcją Hipolita Stupnickiego, prezentująca herby rodowe polskiej szlachty. W książce Niesieckiego przedstawiony został herb Ogończyk (str. 196), który bez wątpienia odpowiada temu znakowi, który został umieszczony na fasadzie poznańskiego budynku:

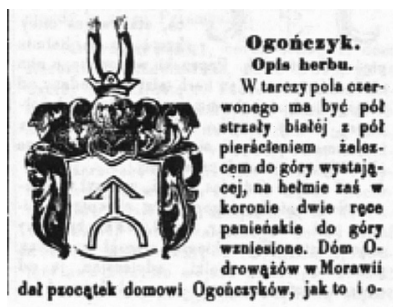

Niesiecki zamieszcza taki opis: W tarczy pola czerwonego ma być ,pół stryały białe’j z poł pierścieniem żelezcem do góry wystającej, na hełmie zaś w koronie dwie ręce panieńskie do góry wzniesione. Dóm Odrowążów w Morawii dał początek domowi Ogończyków, jak to i obóch domów znaki herbowe, choć z niejaką odmianą, zdają się potwierdzać. Zowią ten herb także Pogończykiem: czy to od pogoni za nieprzyjacielem, czy od zabicia pogonina, tego niewiedzieć, odnosi się bowiem do czasów starożytnych, pokrytych mgłą niepewności.

Tym herbem piecxętują się: Augustynowski, Baliński, Białobłocki, Biechowski, Bloch, Bogorski, Borowiecki, Borowski, Broniewski, Butowiecki, Cym, Czarnotulski, Czerski, Dąbrowski, Dobiecki, Dobruchowski, Domajewski, Drwalewski, Drzewiecki, Działyński, Dzięciołowski, Godziszewski, Goleński, Górnicki, Goryński, Gorzechowski, Grodzicki, Gromkowski z tą odmianą, że ręce nad hełmem trzymają pierścień, Hayko, Jakimowicz, Jankowski, Kadzidłowski, Kijowski, Kloczko, Kłodzki, Kochański, Kończa, Kościelecki, Koscielski, Kotliński, Kuciński, Kuczkowski, Kuczyński, Lesiowski, Lętowski, Magnuszewski, Mąkowski, Małanowski, Mijakowski, Mikołajewski, Mirosławski, Mniewski, Mniszek, Morawiec, Murzynowski, Myślakowski, Niedrzwicki, Niedźwiecki, Ogonowski, Paczyński, Padzewski, Paprocki, Parul, Patyński, Pogorski, Powała, Proszyński, Pruszkowski, Radojewski, Radzikowski, Rosnowski, Roszkowski, Rożyński, Sangaw, Sieczkowski, Sierakowski, Siecz- 
kowski, Siewierski, Skarbieński, Skorzewski, Skrzypieński, Sokołowski, Stachowski, Stański, Starosielski, Szwykowski, Tołwiński, Trojanowski, Trzebuchowski, Twardowski, Wiesiołowski, Wlewski, Woliński, Wolski, Woyszyk, Wydzierzewski, Wysocki, Zakrzewski, Zaorski, Zarpalski, Zboiński, Zelski, Zółtowski, Zwolski" (Herbarz polski i imionospis zashużonych w Polsce ludzi wszystkich stanów i czasów: ulożony porzadkiem alfabetycznym na podstawie herbarza Niesieckiego i manuskryptów, Lwów 1855, s. 196-197).

Niestety, w przedstawionym u Niesieckiego herbie, tamga jest w żeńskich rękach, a ponadto berło i miecz wychodzące z korony zniknęły, a wraz z nimi informacje o tym, iż ród, posiadający daną tamgę, znajduje się pod opieką niebiańskiego ptaka KazaK. Albowiem na tronie w postaci Góry Świata Sumeru, przedstawionym w formie ostrosłupa ściętego, siedzi Niebiański Ptak KazaK i korona może należeć tylko do niego.

Sto dwadzieścia rodzin należy do rodu Ogończyk. A co oznacza to słowo w książce W. A. Darowskiego Znaki pieczętne ruskie, na tablicy VIII, rysunek 113 została przedstawiona tamga $\uparrow$-Ogończyk, a na str. 27-28 znajduje się komentarz, który wyjaśnia, że nazwa tamgi ma takie znaczenia: Ogień, Pogański, Ogon (W. A. Darowski, Znaki pieczętne ruskie, Paryż 1862, s. 27-28). Wynika z tego, iż w języku polskim jedno ze znaczeń słowa Ogończyk oznacza Ogień. Ale to tylko podpowiedź, kluczowe słowo. Jak powiedzieliśmy wcześniej, tamga przedstawiona na poznańskim pałacu należy do kazachskiego rodu Adaj. Kluczowe słowo adaj w starożytnym języku turkskim oznacza pisklę (gra słów w języku rosyjskim ognczik-ptënczik). W koncepcji runicznej pisklę niebiańskiego ptaka KazaK wykluwa się w najgorętszym miesiącu roku, to znaczy ${ }_{\mathrm{w}} \mathbf{O g i e n ́}=\mathbf{O d}+\mathbf{A j}=$ miesiąc. Pojęcie Ogień Miesiąc $\mathrm{w}$ koncepcji runicznej graficznie przedstawia się jako Krzyż w łonie Półksiężyca:
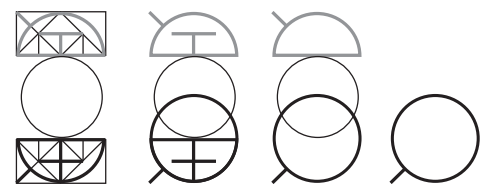

co przekazuje nam informację o połowie, albo, mówiąc inaczej, o środku miesiąca (lipca). A w środku miesiąca księżyc w pełni! W związku z tym termin Ogończyk rozumie się Adaj-Pisklę, co w rzeczywistości jest znaczeniem samej tamgi. Nawiasem mówiąc, wśród Jakutów jest ród Odaj, i wg informacji B. O. Dolgih, ludność basenu rzeki Amgi do tej pory nazy- 
wa się Odajcami (B. O. Dolgih, Rodowy i plemienny skład ludów Syberii w XVII wieku, M. 1960, s. 365, 542-544).

Herb Ogończyk posiada też drugie znaczenie: „W przypadku tego herbu spotyka się także nazwę Pogończyk - a to z powodu pogoni za wrogiem, czy też z powodu poniżenia poganina ..., bez wątpienia świadcząca o tym, że posiadacze tej tamgi byli w przeszłości koczownikami. Zauważmy, że w ruskich kronikach koczowników nazywa się nie inaczej, jak «poganin», chociaż z drugiej strony z całą pewnością wiadomo, że Rusowie byli w bardzo bliskich kontaktach ze swymi południowymi sąsiadami”.

W niniejszym artykule przedstawiliśmy materiały, ukazujące nam przykłady byłej integracji starożytnych Polaków i starożytnych kazachskich rodów, które przesiedliły się z Azji do Europy. Różnorodność języków, kultur, tradycji i wyznań w istocie zupełnie różnych od siebie narodów nie okazała się przeszkodą w ich zjednoczeniu. Świadczy to o tym, że rzeczywista integracja nie zna żadnych barier.

Thumaczenie: Jerzy Laskowski

\section{Ancient Integration of Nations in Europe and Asia, or the Polish Legend about the Origins of the Kazakhs}

\section{Summary}

The paper presents materials evidencing the examples of former integration between Poles and Kazakh families that relocated from Asia to Europe in antiquity. The diversity of the languages, cultures, traditions and religions of these actually very different nations turned out not to be an impediment to their union. This demonstrates that true integration knows no barriers. 